\title{
A PREFACE ON EMPIRICAL BIBLICAL HERMENEUTICS
}

\author{
Ernst M Conradie \\ Department of Religion and Theology \\ University of the Western Cape \\ Associate Editor Scriptura
}

$\mathrm{T}$ his edition of Scriptura contains a number of contributions deriving from an empirical research project on Biblical interpretation within the context of established Bible study groups. A number of Biblical scholars and theologians from the Western Cape region participated in this research project between 1996 and 2001. The first contribution in this volume offers a detailed chronicle of this research project.

This research project builds on several earlier theoretical contributions to the field of Biblical hermeneutics. In the Western Cape region, the pioneering work of scholars such Denise Ackerman, ${ }^{1}$ Bernard Combrink, ${ }^{2}$ Ferdinand Deist, ${ }^{3}$ Bernard Lategan, ${ }^{4}$ Hennie Rossouw, ${ }^{5}$ and Dirkie Smit ${ }^{6}$ immediately comes to mind.

This research projects builds on such theoretical work by entering in the emerging discipline of empirical Biblical hermeneutics. The question that is addressed here is a deceptively simple one: What happens when people actually read the Bible? Of course, the Bible is read in many different contexts, including Christian churches, universities, schools and in the broader society. And it is read in many different ways, with different interpretative interests and with different praxeological impacts in terms of theological positions, forms of spirituality and Christian praxis. This has become clear from many earlier contributions on contextual hermeneutics. However, comparatively little empirical research has been done on how the Bible is read within such contexts.

In South Africa some important work has been done in this field by Gerald West, together with the Institute for the Study of the Bible at the University of Natal (Pietermartizburg). West is specifically interested in the question as to how the Bible is read by poor and marginalised people in South African townships. He draws on these readings (i.e. from the "Academy of the poor"7) in order to promote a Biblical hermeneutics of liberation $^{8}$ that would be sensitive to issues of gender, race and class.

1. See especially Ackerman (1993).

2. See the earlier contributions by Combrink on structural analysis and his later contributions on a sociorhetorical approach to Biblical hermeneutics (Combrink 1983, 1988).

3. See the widely used textbook by Deist \& Burden (1980) as well as a large number of articles on Biblical hermeneutics in Deist's considerable oeuvre.

4. The pioneering work of Bernard Lategan on hermeneutical theory deserves special mentioning. Lategan, the founder and first editor of Scriptura, initiated the Centre for Contextual Hermeneutics that made several contributions on the role of the socio-political context within which the Bible is interpreted. He also played a leading role in organising a high profile annual seminar on contextual hermeneutics. This seminar produced a large number of contributions that were published in Scriptura on an ongoing basis. See, among his many contributions, especially a famous article on paradigms shifts in Biblical interpretation (Lategan 1984). For an appraisal of Lategan's contributions, see Smit (1994).

5. See, for example, Rossouw's important contribution on Biblical hermeneutics in the very first volume of Scriptura (Rossouw 1980).

6. See especially Smit $(1987,1998 a, 1998 b)$ and his important contributions on the ethics of interpretation (Smit 1990a, 1990b).

7. See the title of the recent work by West (1999).

8. See the title of West's doctoral dissertation, published by Cluster Publications (1991). 
Empirical Biblical hermeneutics is indeed an emerging discipline. Relatively little empirical work and critical analysis has been done thus far on the dynamics and social impact of Bible study. In Latin America some pioneering work has been done in this regard by Ernesto Cardenal $^{9}$ and Carlos Mesters ${ }^{10}$ on reading the Bible in base Christian communities. Emancipatory reading experiences of Christian communities in various other Third World contexts have also been collected and published. ${ }^{11}$ More recently, an intercontinental research project has been launched through the initiative of Dr J.H. de Wit at the Free University of Amsterdam. ${ }^{12}$ The title of this project is significant: "Through the eyes of an Other: An experiment in reading the Bible inter-culturally". It has a comparative focus and will investigate the ways in which particular Biblical texts are read in different cultural contexts. Several scholars who participated in the Western Cape project will be involved in this larger project too.

The research project that is documented here focuses on the ways in which the Bible is read within the context of established Bible study groups. ${ }^{13}$ This is distinct from other work on Biblical interpretation in the context of sermons,${ }^{14}$ personal devotions, the use of the Bible in literary work, in public speeches, etc. In several ways the empirical work of West formed the stimulus behind this project. However, this project deliberately differs from West's work in a number of important ways:

1) The Bible study groups that are investigated here are selected from well-established Bible study groups.

2) All the groups read the people from within an ecclesial context.

3) The research project was not aimed at promoting a particular interpretative ethos (e.g. a "hermeneutics of liberation"); it investigated the ways in which the Bible is actually being read in these groups, for better or for worse.

4) The project attempted to minimise the possible impact of the research activities on the Bible study group. It did not, for example, make use of participant observers. Instead, the Bible study groups were asked to read a particular text "in the way they normally do."

The first part of this edition of Scriptura contains the results of the empirical research. The first contribution provides a chronicle of the regional research project over a six-year period. Two phases of this project may be identified, i.e. a "pilot" project and a second phase of the project. The pilot project did some exploratory research on Biblical interpretation within established Bible study groups. This served the purpose of theoretical clarification and the generation of hypotheses. On the basis of such hypotheses a new project was launched in 1999. The results of this second phase of the project is documented in six contributions that provide a "thick description" of the Bible study events of the six Bible study groups that participated in the project. ${ }^{15}$ This is followed by a critical

9. See Cardenal (1976).

10. See, for example, Mesters $(1980,1981)$.

11 See also Sugirtharajah (1995), Segovia \&Tolbert (1995).

12. See also De Wit (1991).

13 See the study by Fowl \& Jones (1991) on "Reading in communion", also Van Zyl (1994).

14. See specially Müller (1992).

15. The research team wishes to express it sincere gratitude to the members of the various Bible study groups that participated in the first and the second phases of this research project. Their willingness to cooperate in this regard, often without a clear sense of what the outcomes of the project would be, is indeed highly appreciated. The research team also appreciates the fact that the groups allowed their agendas to be interrupted by the agenda of the research team (i.e. the reading of particular texts), that they were willing to spend some time on this process and that they allowed a tape or video recording to be made of their Bible study events. They also helped the research team to understand that the role of trained Biblical readers as outsiders to established Bible study groups is far more problematic than what one may imagined. 
assessment of the results of this empirical research project. This discussion yields a number of insights that highlights the significance of this research:

- In modern Biblical scholarship there is a pervasive tendency to downplay the influence of Christian doctrine on Biblical exegesis. This is hardly surprising given the widespread abuse of Biblical texts in Systematic Theology to "prove" particular theological views by simply quoting "proof texts", very often out of context. However, as this research project amply illustrates, the influence of Christian doctrine and ecclesial traditions on Biblical interpretation cannot be denied. In fact, the use of "doctrinal keys" is necessary for the dimension of application in Biblical interpretation. Where the influence of doctrine on Biblical interpretation is denied, it simply resurfaces, often in less sophisticated forms. The evidence from this research project indicates that most established Bible study groups do show a strong need for a confirmation and reassurance of the legitimacy of their doctrinal keys.

- Group dynamics play a crucial role in Biblical interpretation in a group context. The purpose(s) for which a group gathers will structure the ways in which the Bible is read and applied in a particular context. In the case of established Bible study groups (especially where these groups form part of local Christian communities) these purposes include worship, spiritual growth, Biblical knowledge, a prayer and support group, a social gathering, etc. This would be significantly different from groups that are formed outside an ecclesial context, on an ad hoc basis and for the purpose of research only. An ad hoc group will probably read the Bible in terms of the way in which the group perceives the reason why the group was formed in the first place. Indeed, interpretive interests dominate any Bible study event. If a group is established for the sake of a liberatory reading of the Bible, that will be the result. If a group is established to reinforce and support the religious beliefs, convictions and values of a particular ecclesial tradition, the Bible will be read accordingly.

- Biblical interpretation is an incredibly complex process. Any attempt to describe or model this process tends to become formalistic and can scarcely do justice to the rich complexity of particular Bible study events. The experience gained during this research project indicated that every previous attempt at modelling the process remained inadequate whenever a new Bible study event was analysed. Perhaps this illustrates the postmodern emphasis on diverse connections or "inter-textuality" in which the Biblical text, its co-texts, its socio-historical context, the history of interpretation, the group's own history and ethos, the diverse experiences of each member of the group and the broader contemporary context interact with one another in an incalculable number of ways.

- The relationship between ordinary readers and trained or specialist readers of the Bible remains highly problematic. ${ }^{16}$ There is no doubt that the presence of participant observers will influence, indeed dominate, the way in which the Bible is read during a particular Bible study event. At the same time, as this research project illustrates, if trained readers maintain an academic distance from Bible study events, this precludes any fruitful interaction between trained readers and ordinary readers. It only increases the gap and highlights the problem. The inputs of trained readers are valued by Bible study groups on the following conditions:

16. See Gerald West (1999a:34-62, 1999b) on the notion of "reading with" and a dialogical model of reading the Bible. West argues that both an uncritical "listening to" that romanticises and idealises the interpretations of the poor and marginalised and an arrogant "speaking for" that minimises and rationalises such interpretations must be rejected. 
- A relationship of trust has to exist between trained readers and a Bible study group. This is, for example, possible where the trained reader is a normal member of the group, where the trained reader is the local pastor with whom the group has regular contact in another context, or where the trained reader is a well-respected author. The availability of information will not necessarily be sufficient by itself. Such information will not be appropriated if there is a lack of communication or trust. The information provided by the trained reader cannot be separated from her or his personal integrity as perceived by the group. Such personal integrity is of particular importance where there are significant differences between the group and the trained reader in terms of education, class, gender, race or age.

- Any ad hoc inputs by trained readers within particular Bible study events will not necessarily be assimilated by a Bible study group. The availability of potentially valuable information does not enhance Biblical interpretation by itself. The appropriation of inputs from trained readers is only possible where a group has developed a certain hermeneutical competence over a period of time. A group who has, for example, developed a sensitivity for literary genre will be able to integrate any literary inputs much easier. Such hermeneutical competence requires exposure and guidance by trained readers over a period that is long enough to acquire such skills. A Bible study group needs a frame of reference in order to value and assimilate any inputs by trained readers.

The second part of this edition of Scriptura contains some of the theoretical contributions derived from the research project. These theoretical contributions reflect on various aspects of Biblical interpretation in an attempt to develop some descriptive tools that can aid an empirical analysis of Bible study events. These contributions draw on and develop some of the authors' earlier contributions on Biblical hermeneutics. ${ }^{17}$

One curious aspect of the interaction between these theoretical contributions and the empirical research may be noted here. From one perspective, the theoretical contributions contain few new insights. They tend to draw on and reinforce existing analyses of Biblical interpretation. Nevertheless, the experience of the research group was continuously one of finding itself in uncharted territory. The comment was often heard during meetings of the research group that "What we are saying seems so obvious that it probably only reiterates what has been said numerous times before. Yet, almost no one seems to have done the work that we are doing in quite the same way." This observation is probably due to the fact that empirical Biblical hermeneutics is an emerging discipline. The theoretical contributions clearly draw on many earlier studies on Biblical hermeneutics. It also demonstrates, in broad terms, the validity of such work. However, what this research project attempted to do was to test the adequacy of existing hermeneutical theories through empirical observations on the ways in which established Bible study groups read the Bible. It asked the question whether these theories can do justice to concrete cases studies of Biblical interpretation. It investigated the many factors that may influence Biblical interpretation. It soon discovered that no hermeneutical theory can be sophisticated enough to describe the incredibly complex process of reading the Bible in a group context. New perspectives and variables, that the existing theories do not account for sufficiently, emerged in the group discussions on an ongoing basis. Nevertheless, at least some members of the research group remained convinced of the basic validity and value of some broad hermeneutical theories. Such theoretical contributions are included in the second part of this edition of Scriptura.

17. See especially Conradie et al (1995), Botha, Jonker \& Conradie (1997), Conradie \& Jonker (2001)., Jonker $(1996,1998,2000)$. 
Lawrie proposes that three aspects of Biblical interpretation may be distinguished, i.e. reading, interpretation and re-inscription. Jonker documents a number of way in which the event of Biblical interpretation has been mapped by various scholars. Conradie investigates the role of two aspects of Biblical interpretation in separate contributions, i.e. the influence of doctrinal keys and of group dynamics on Bible study within established Bible study groups. In a concluding essay Conradie and Jonker suggests various criteria that may be identified for relative adequacy in Biblical interpretation. 


\section{BIBLIOGRAPHY}

Ackermann, DM 1993. Liberating the Word: Some thoughts on feminist hermeneutics. Scriptura 44, 1-18.

Botha, J, Conradie, EM \& Jonker, LC 1997. Die Bybel in fokus. Leesgids vir 'n nuwe tyd. Kaapstad: Lux Verbi.

Cardenal, E 1976. The gospel in Solentiname. Maryknoll: Orbis Books.

Combrink, HJB 1983. Die pendulum swaai terug - enkele opmerkinge oor metodes van Skrifinterpretasie. Skrif en Kerk 4:2, 3-15.

Combrink, HJB 1984. Multiple meaning and/or multiple interpretation of a text. Neotestamentica 18, 26-37.

Combrink, HJB 1988. Readings, readers and authors: an orientation, Neotestamentica 22, 189-204.

Conradie, EM \& Jonker, LC 2001. Angling for interpretation. A guide to understand the Bible better. Study Guides in Religion and Theology 4. Bellville: University of the Western Cape.

Conradie, EM et al 1995. Fishing for Jonah. Various approaches to Biblical interpretation. Bellville: UWC Publications.

De Wit, JH 1991. Leerlingen van de armen. Amsterdam.

Deist, FE \& Burden, JJ 1980. An ABC of Biblical exegesis. Pretoria: JL van Schaik.

Deist, FE 1988. "Gekontroleerde" eksegese en/of "kreatiewe" uitleg. Hervormde Teologiese Studies 44:1, 39-54.

Deist, FE 1989. Eksegese as "leeskompetensie": Oor onderrig in Skrifuitleg. Nederduitse Gereformeerde Teologiese Tydskrif 30:1, 56-63.

Fowl, SE \& Jones, LG 1991. Reading in communion: Scripture and ethics in Christian life. London: SPCK.

Jonker, LC 1993. "Text" in a multidimensional exegetical approach. Scriptura 46, 100-115.

Jonker, LC 1996. On plotting the exegetical-hermeneutical landscape. Scriptura 59, 397412.

Jonker, LC 1998. Reading Jonah multi-dimensionally: A multidimensional reading strategy for Biblical interpretation. Scriptura 64, 1-16.

Jonker, LC 2000. The influence of social transformation on the interpretation of the Bible: A Methodological reflection. Scriptura 72, 1-16.

Lategan, BC 1984. Current issues in the hermeneutical debate. Neotestamentica 18, 1-17.

Mesters, C 1980. How the Bible is interpreted in some Basic Christian communities in Brazil. In Küng, H \& Moltmann, J (eds): Conflicting ways of interpreting the Bible, 41-46. New York: The Seabury Press.

Mesters, C 1981. The use of the Bible in Christian communities of the common people. In: Torres, S \& Eagleton, J (eds): The challenge of Basic Christian Communities, Maryknoll: Orbis Books.

Müller, BA 1992. Skrifgebruik in die onafhanklike Afrika kerke. Fakulteit Teologie, Universiteit van Stellenbosch. (mimeo)

Rossouw, HW 1980. Hoe moet 'n mens die Bybel lees? Die hermeneutiese probleem. Scriptura 1, 7-28.

Segovia, FF \& Tolbert, AM 1995. Reading from this place I \& II. Minneapolis: Fortress Press. 
Smit, D J 1987. Hoe verstaan ons wat ons lees? Kaapstad: N G Kerk-Uitgewers.

Smit, DJ 1990. The ethics of interpretation - new voices from the USA. Scriptura 33, 1628.

Smit, DJ 1990b. The ethics of interpretation - and South Africa. Scriptura 33, 29-43.

Smit, DJ 1991. The Bible and ethos in a new South Africa. Scriptura 37, 61-67.

Smit, DJ 1994. A story of contextual hermeneutics and the integrity of New Testament scholarship in South Africa. Neotestamentica 28:2, 265-289..

Smit, DJ 1998a. Biblical hermeneutics: The first 19 centuries. In: Maimela, S \& König, A 1998. Initiation into theology: The rich variety of theology and hermeneutics, 275296. Pretoria: Van Schaik.

Smit, DJ 1998b. Biblical hermeneutics: the $20^{\text {th }}$ century. In: Maimela, S \& König, A 1998. Initiation into theology: The rich variety of theology and hermeneutics, 297-317. Pretoria: Van Schaik.

Sugirtharajah, AS 1995. Voices from the margin. New York.

Van Zyl, DC 1994. Die bydrae van Afrika-Christene tot die interpretasie van die Bybel die interpreterende gemeenskap. Nederduits Gereformeerde Teologiese Tydskrif 35:3, 359-366.

West, GO 1991. Biblical hermeneutics of liberation. Modes of reading the Bible in the South African context. Pietermaritzburg: Cluster Publications.

West, GO 1995. Reading the Bible in Africa: Constructing our own discourse. Bulletin for Contextual Theology in Southern Africa 2:2, 1-5.

West, GO 1999. The academy of the poor: Towards a dialogical reading of the Bible. Sheffield: Sheffield Academic Press.

West, GO 1999. Reading other-wise: Re-envisioning the reading practices and place of the socially engaged biblical scholar. Scriptura 68, 49-66. 